doi:10.31674/mjn.2021.v12i04.006

\title{
MJN THE RELATIONSHIP BETWEEN ARM EXERCISES AND THE INCIDENCE OF LYMPHEDEMA IN POST-MASTECTOMY BREAST CANCER PATIENTS IN RSUPH ADAM MALIK MEDAN
}

\author{
Helinida Saragih*, Ikhsanudin A. Harahap, Nurmaini \\ Faculty of Nursing, University of Sumatera Utara, Indonesia \\ *Corresponding Author's Email: elinidasaragih@gmail.com
}

\begin{abstract}
Breast cancer is a malignant neoplasm, an abnormal growth of breast tissue growing into the surrounding stromal tissue, grows infiltrative and destructive, and can metastasize. Every breast cancer patient experience various side effect due to various treatments. This is because the therapy that each patient gets varies and also cancer patients have different genetic backgrounds and different environments. Mastectomy in breast cancer patients can cause many patients to suffer from decreased joint mobility, lymphedema, and limitation in daily activities. These complaints can be controlled with arm exercises. Arm exercises are done to improve circulation and muscle strength and to prevent joint stiffness, preventing lymphedema from occurring. The purpose of this study was to determine the effect of arm exercises on lymphedema prevention. The research design was a quasi-experimental study with a sample size of 64 respondents. The results of the study were $p$ value $=0.001$. It is hoped that this study can be used as an education for postmastectomy patients to improve lymph flow so that lymph flow obstruction does not occur.
\end{abstract}

Keywords: Breast Cancer; Mastectomy; Lymphedema; Arm Exercises

\section{INTRODUCTION}

Breast cancer is a malignant neoplasm, an abnormal growth of breast tissue that invade the surrounding tissue, grows infiltrative and destructive, and can metastasize. Breast tumors grow progressively, and enlarge relatively quickly. Cancer is a disease with a multifactorial cause that is formed over a long period of time and progresses through different stages (Oemiati et al., 2011).

The most commonly used procedures for the management of breast cancer are mastectomy with or without reconstruction and surgery, combined with radiation therapy (Dewi, 2004). Mastectomy is a surgical removal of breast tissue (Brunner \& Suddart, 2013). The scope of the resection includes the entire breast, skin, pectoralis major and minor muscles, axillary lymph nodes including internal mammary or supraclavicular depending on the type of surgery or mastectomy performed (Andrews, 2010).
There are several types of mastectomy performed on breast cancer patients that can cause lymphedema according to Andrews (2010), namely radical mastectomy, radical modified mastectomy (mastectomy patey), and simple or total mastectomy. Total mastectomy with axillary lymph node dissection can have several sequels including lymphedema post mastectomy (Lee et al., 2013).

If lymphedema occurs, its spread is related to the number of colorectal lymphatic channels removed during surgery. Patients need information about possible postoperative surgical edema and strategies to prevent it. Scratches, bruises, and infection at the operated site increase the likelihood of lymphedema (Smeltzer, 2002). Lymphedema also predisposes patients to the development of infection, decreased functional ability and reduced range of motion (Rivere \& Klimberg, 2016).

Complaints experienced as a result of a mastectomy 
can be resolved by carrying out various ambulation. Ambulances are allowed when the patient is free from anesthesia and can tolerate fluids. Arm exercises in breast cancer can reduce clinical symptoms of breast cancer post medical therapy, patients who practice regularly get a reduction in post-therapy clinical symptoms (lymphodenopathy, fatigue, pain, nausea) and also if these symptoms arise then the severity is not as high as if they don't practice regularly (Wiharja, 2016).

Arm exercises are the key to improving body condition. It is also used as a therapy to form deformities or to restore the whole body to a state of maximum health so that there will be physiological changes in the body system (Perry \& Potter, 2006). Post-mastectomy side effects must be overcome by doing arm exercises. According to Toglia (2007) there is a fact that postoperative arm exercises can reduce the risk of lymphedema and shoulder stiffness and inhibit symptoms such as weakness, muscle atrophy, bone pain, and decreased metabolism.

\section{METHODOLOGY}

Design of this Research: is quantitative research or quantitative design with a quasi-experimental design approach (Polit \& Beck, 2012). A quasi-experimental design is a study that tests an intervention on a group of subjects with or without a comparison but is not randomized to enter the subject into a treatment or control group (Dharma, 2015). An initial measurement (pretest) was carried out in all groups, both in the intervention group and the control group. Furthermore, in the intervention group according to the planned protocol, while in the control group there was no intervention. The quasi-experimental design used treatment group A (arm exercise) and control group B.

Statistical Analysis: Univariate analysis was carried out using descriptive analysis through the distribution of frequency and percentage of data including age, education, occupation and data on arm measurements before the intervention and after the intervention on both treatment and control group respondents.

The first bivariate analysis was carried out by the data normality test with the Kolmogorov-Smirnov data with normal distribution where the $p$-value> 0.005 . Then the paired t test was carried out to test the mean difference between the same 2 groups (pretest and postest). Then the Independent $t$ test was carried out to see the mean of the 2 different groups.

\section{RESULTS}

Based on the results of the study, more than two thirds $(78.12 \%)$ in the intervention group were in the middle adult age range (41-60 years) with an average age of 49.91 years $(\mathrm{SD}=9.623)$. Whereas in the control group the majority of respondents $(87.5 \%)$ were middle adults (41-60 years) with an average age of 52.97 years $(\mathrm{SD}=6.453)$. Based on education level, half $(50 \%)$ of the intervention group had a high school / equivalent graduate education. Whereas in the control group more than half $(53.12 \%)$ of education had graduated from high school / equivalent. Based on the level of employment, more than half $(52.12 \%)$ of the intervention group worked as entrepreneurs, while in the control group more than half $(62.5 \%)$ were selfemployed. Can be seen in the table.

Table 1: Distribution of Frequency and Percentage of Demographic Data Characteristics of Post-Mastectomy Breast Cancer Patients $(n=64)$

\begin{tabular}{|l|c|c|c|c|c|}
\hline \multicolumn{2}{|c|}{} & \multicolumn{2}{|c|}{ Intervention } & \multicolumn{2}{c|}{ Control } \\
\hline $\begin{array}{l}\text { Respondenr } \\
\text { Characteristic }\end{array}$ & Categories & $\mathbf{f}$ & $\%$ & $\mathbf{f}$ & $\%$ \\
\hline Age & $18-40$ (Early Adulthood) & 4 & 12.8 & 1 & 3.12 \\
& $41-60$ (Middle Adult) & 25 & 78.12 & 28 & 87.5 \\
& $>60$ & 3 & 9.37 & 3 & 9.37 \\
\hline Education & SD & 4 & 12.5 & 3 & 9.37 \\
& Junior High & 7 & 21.87 & 2 & 6.25 \\
& High School & 16 & 50 & 17 & 53.12 \\
& College & 5 & 15.62 & 10 & 31.25 \\
\hline Profession & Self-employed & 17 & 52.12 & 20 & 62.5 \\
& Civil servants & 2 & 6.25 & 6 & 18.75 \\
& Farming & 5 & 15.62 & 3 & 9.37 \\
& Private Employees & 2 & 6.25 & - & - \\
& Housewife & 6 & 18.75 & 3 & 9.37 \\
& & & & & \\
\hline
\end{tabular}

The results showed that breast cancer patients after mastectomy at Haji Adam Malik General Hospital Medan in the majority control group (87.5\%) had lymphedema and less than a quarter (12.5\%) did not experience lymphedema.

Table 2: Frequency Distribution of Patients with Lymphedema and No Lymphedema After Arm Exercises for Breast Cancer Patients After Mastectomy $(n=64)$

\begin{tabular}{|l|c|c|c|c|}
\hline Group & \multicolumn{2}{|c|}{ Lymphedema } & \multicolumn{2}{c|}{ Non Lymphedema } \\
\hline & $\mathrm{f}$ & $\%$ & $\mathrm{f}$ & $\%$ \\
\hline Intervention & 0 & 0 & 32 & 100 \\
\hline Control & 28 & 87.5 & 4 & 12.5 \\
\hline
\end{tabular}


Table 3: Results of the Post-Test Analysis for the Intervention Group and the Post-Test for the Control Group in Post-Mastectomy Patients in the Control Group and Intervention Group

\begin{tabular}{|l|c|c|c|c|}
\hline Arm size (cm) & Difference average \pm SD & $\mathbf{9 5} \% \mathbf{C I}$ & $\boldsymbol{t}$ & $\boldsymbol{p}$ \\
\hline UA & $4.063 \pm 3.614$ & $5.451 \pm 2.674$ & -5.874 & 0.001 \\
\hline FA & $7.531 \pm 2.348$ & $8.505 \pm 6.558$ & -15.462 & 0.001 \\
\hline W & $4.531 \pm 1.866$ & $5.319 \pm 3.744$ & -11.502 & 0.001 \\
\hline H & $4.500 \pm 1.930$ & $5.354 \pm 3.646$ & -10.535 & 0.001 \\
\hline \multicolumn{4}{|l|}{ UA=Upper Arm, } & FA= Fore Arm, W= Wrist, H=Hand \\
\hline
\end{tabular}

\section{DISCUSSION}

Based on the results of arm measurements before doing arm exercises in the two groups, namely the control group and the intervention group, the results of the measurement of the arm before the intervention were not so different in the two groups because there was no exercise and the measurement was carried out one day after post mastectomy. According to research by Dennis (2009) lymphedema in the arm will be seen more than 48 hours post mastectomy if the patient does not do arm mobilization or arm movements. This is due to the fact that an increase in the accumulation of fluid in the lymph because of the lymph node removal factor. So patients who have had a mastectomy have to do exercises in the affected arm. The results of this study are in line with the research of Gautam, 2011 which states that pre-intervention who does not get any exercise cannot be assessed for the incidence of lymphedema because the initial measurement is only to see the value of the arm size in each arm to be measured. Exercises in the intervention group helped post mastectomy patients to restore range of motion, maintain muscle tone, and improve blood and lymph circulation (Dell, 2001). Based on the results of the study, the researcher saw a significant difference according to body weight in the pre and post intervention arm sizes of the intervention group and the control group. Based on the research of Gautam (2011), the value of arm size in the control group and the intervention group will definitely be very different, influenced by the training given to the intervention group.

According to research by Dennis (2009) lymphedema in the arm will be seen more than 48 hours post mastectomy if the patient does not do arm mobilization or arm movements, when there is an increase in the accumulation of fluid in the lymph because of the lymph node removal factor. So patients who have had a mastectomy have to do exercises on the affected arm. The results of this study are in line with the research of Gautam, 2011 which states that pre-intervention who does not get any exercise cannot be assessed for the incidence of lymphedema because the initial measurement is only to see the value of the arm size in each arm to be measured.

Exercises in the intervention group helped post mastectomy patients to restore range of motion, maintain muscle tone, and improve blood and lymph circulation (Dell, 2001). Based on the results of the study, the researcher saw a significant difference according to body weight in the pre and post intervention arm sizes of the intervention group and the control group. Based on the research of Gautam (2011), the value of arm size in the control group and the intervention group will definitely be very different, influenced by the training given to the intervention group.

Research by Dell (2001) states that the increase in arm size after mastectomy is influenced by several factors, namely the removal of lymph nodes, lack of movement exercises in the affected arm, and the effect of infection. The results of a study by Dell (2001) regarding the range of arm exercises in postmastectomy breast cancer patients obtained results from 94 respondents who participated in post mastectomy arm exercises, the majority $(90.2 \%)$ of respondents avoided lymphedema.

\section{CONCLUSION}

The majority of lymphedema incidence in the control group (87.5\%) had lymphedema and $12.5 \%$ did not have lymphedema. In the intervention group lymphedema did not occur.

For nursing services, in order to provide more knowledge for patients who have just finished mastectomy surgery so that all post mastectomy patients can perform arm exercises at home after they are discharged from the hospital.

For educational institutions, the data obtained by researchers can be used as a reference in carrying out arm exercises for post-mastectomy breast cancer patients and can also be used as additional laboratory practices / skills.

For future researchers, it is hoped that further researchers can examine the incidence of lymphedema by examining whether there are lymph nodes and what grade. 


\section{Conflict of Interests}

The authors declare that they have no conflict of interest

\section{ACKNOWLEDGMENT}

Special thanks and gratitude are offered to the medical staff and patients in oncology department at Al Fardose

\section{REFERENCES}

Andrews, G. (2010). Buku Ajar Kesehatan Reproduksi Wanita. $2^{\text {nd }}$ edition, Jakarta: Penerbit Buku Kedokteran EGC.

Brunner, S. \& Suddarth, D. Buku ajar keperawatan medikal bedah Brunner \& Suddarth. Vol. 1. $8^{\text {th }} \quad$ ed). (Agung Waluyo, Made Karyasa, Julia, Y. Kuncara \& Yasmin Asih, Penerjemah). Jakarta: Penerbit Buku Kedokteran EGC.

Dell, D. (2001). Regaining range of motion after breast surgery. Nursing, 31(10), 50.

Dennis, L.K., Tsai, R.J., Lynch, C.F., Snetselaar, L. G., Zamba, G.K.D. \& Scott-Cornner, C. (2009). The Risk of Developing Arm Lymphedema Among Breast Cancer Survivors: A Meta-Analysis of Treatment Factors. Annals of Surgical Oncology, 16, hlm 1959-1972.

Dewi, F.I.R. \& Djoenaina, V.M. (2004). Hubungan antara resiliensi dengan depresi pada perempuan pasca pengangkatan payudara (mastektomi). Journal Psikologi, 2(2), pp 101-120.

Dharma Kelana, K. (2011). Metodologi Penelitian Keperawatan: Panduan Melaksanakan dan Menerapkan Hasil Penelitian. Jakarta: Trans Info Media.

Gautam, A.P., Maiya, A.G. \& Vidyasagar, M.S. (2011). Effect of Home-Based Exercise Program on Lymphedema and Quality of Life in Female Postmastectomy Patients: Pre-Post Intervention Study. Journal of Rehabilitation Research \& Development, 48(10), pp 1261-1268.

Lee, K. T., Mun, G. H., Lim, S. Y., Pyon, J. K., Oh, K. P. \& Bang, S. I. (2013). The Impact of Immediate Breast Reconstruction on Post-Mastectomy Lymphedema in Patients Undergoing Modified Radikal Mastectomy. Elsevier Ltd. All Rights Reserved, 28(1), pp 59-64.

Oemiati, R., Rahajeng, E. \& Kristanto, A.Y. (2012). Prevalensi tumor dan beberapa faktor yang mempengaruhinya di Indonesia. Buletin Penelitian Kesehatan, 39(4).

Polit, D.F. \& Beck, C.T. (2012). Nursing Research: Generating and Assessing Evidence for Nursing Practice. Philadelphia: Lippincott Williams \& Wilkins.

Potter, P.A. \& Perry, A.G. (2006). Buku Ajar Fundamental Keperawatan. Jakarta: EGC

Rivere, A. E. \& Klimberg, V. S. (2018). Lymphedema in the postmastectomy patient: pathophysiology, prevention, and management. In The Breast (pp. 514-530). Elsevier.

Smeltzer, S.C. \& Bare, B.G. (2001). Buku Ajar Keperawatan Medikal Bedah Brunner \& Suddarth, Edisi 8 Volume 2 , Jakarta: Buku Kedokteran EGC.

Tsai, R.J., Dennis, L.K., Lynch, C.F., Snetselaar, L.G., Zamba, G.K. \& Scott-Conner, C. (2009). The risk of developing arm lymphedema among breast cancer survivors: a meta-analysis of treatment factors. Annals of surgical oncology, 16(7), pp 1959-1972.

Wiharja, A. (2016). The New Perspective of Exercise as a Breast Cancer Therapy. Journal of Medicine and Health. $1(1)$, pp 287-295. 